\title{
MODOS DE SER E SENTIR: ENTRELAÇANDO NARRATIVAS DAS CRIANÇAS E PROFESSORAS QUILOMBOLAS
}

\author{
Noelia da Silva Miranda de Araujo ${ }^{1}$ \\ Patrícia Gomes Rufino Andrade ${ }^{2}$ \\ Sidineide Vidigal Reginaldo ${ }^{3}$ \\ Genilda Cassiano ${ }^{4}$
}

\begin{abstract}
RESUMO: A proposta pedagógica da escola da comunidade quilombola de Linharinho em Conceição da Barra-ES tem sido formulada observando sua inserção dentro dessa comunidade tradicional. Este texto traz as reflexões das professoras pesquisadoras que se debruçam sobre a seguinte pergunta: o que as crianças quilombolas têm a nos dizer em seus modos de ser e de sentir a escola e comunidade? $\mathrm{O}$ objetivo do nosso trabalho é valorizar as narrativas das crianças para se pensar ações pedagógicas e implementação de políticas públicas na comunidade. Concluímos que a escola e comunidade estão na busca de alternativas, ouvindo as narrativas dos estudantes, para que com eles e para eles se construam novos horizontes, valorizando os saberes, as culturas e tradições da comunidade.
\end{abstract}

Palavras-chave: Quilombola. Educação quilombola. Narrativas. Educação antirracista.

\footnotetext{
${ }^{1}$ Pedagoga. Mestranda em Educação no PPGMPE-UFES. Professora efetiva e pesquisadora na rede pública de ensino da Prefeitura Municipal de Vitória-ES. E-mail: noymestrado@gmail.com

${ }^{2}$ Pedagoga. Doutora em Educação pela UFES. Docente do Programa de Pós-Graduação Mestrado Profissional em Educação (PPGMPE). E-mail: patiruf.neab@gmail.com

${ }^{3}$ Pedagoga. Professora da Educação Quilombola/ Coordenadora da Educação do Campo e Comissão de Estudos Afro-Brasileiros na Secretaria de Educação de Conceição da Barra - ES. E-mail: sidineide.vidigal2017@gmail.com

${ }^{4}$ Pedagoga. Professora da Educação Quilombola- Sala Multisseriada na EMEF "Linhares". E-mail: genildacassiano@gmail.com
} 


\title{
WAYS OF BEING AND FEELING - INTERTWINING NARRATIVES OF QUILOMBOLA CHILDREN AND TEACHERS
}

\begin{abstract}
The pedagogical proposal of the school of the quilombola community of Linharinho in Conceição da Barra-ES has been formulated observing its insertion into this traditional community. This text points out the reflections of the teacher researchers who focus on the following question: what do the quilombola children have to say to us in their ways of being and feeling the school and community? The objective of our work is to value the children's narratives to think of pedagogical actions and implementation of public policies in the community. We conclude that the school and community present itself in the search for alternatives listening to the students' narratives, so that with them and for them new horizons are built, valuing the knowledge, cultures and traditions of the community.
\end{abstract}

Keywords: Quilombola. Quilombola education. Narratives. Antiracist education.

\section{FORMAS DE SER Y SENTIR: NARRACIONES ENTRELAZADAS DE NIÑOS Y MAESTROS QUILOMBOLAS}

RESUMEN: La propuesta pedagógica de la escuela de la comunidad quilombola de Linharinho en Conceição da Barra-ES ha sido formulada observando su inserción en esta comunidad tradicional. Este texto señala las reflexiones de los profesores investigadores que se centran en la siguiente pregunta: ¿Qué tienen que decirnos los niños quilombolas en su manera de ser y sentir la escuela y la comunidad? EI objetivo de nuestro trabajo es valorar las narrativas de los niños para pensar en acciones pedagógicas e implementación de políticas públicas en la comunidad. Concluimos que la escuela y la comunidad buscan alternativas escuchando las narrativas de los alumnos, para que con ellos y para ellos se construyan nuevos horizontes, valorando los conocimientos, culturas y tradiciones de la comunidad.

Palabras clave: Quilombolas. Educación quilombola. Narrativas. Educación antirracista.

\section{Para início de conversa}

Tratar dos modos de ser e sentir a sua ancestralidade é algo desafiador, principalmente quando se trata de escrita sobre crianças quilombolas, dificilmente poderíamos escrever qualquer linha sem antes ouvi-las e senti-las. Desse modo, as vozes das crianças estão presentes em diálogos com suas professoras. Essas práticas 
se compõem em construir outra proposta de projeto pedagógico, descolonizado, no qual os narradores sejam os sujeitos da história e vivências.

Este texto foi concebido no caminhar da pesquisa-ação: "Formação de professoras/es e lideranças quilombolas: a importância das narrativas e histórias africanas e afro-brasileiras" em curso, e contou com a união e colaboração de mulheres negras professoras, pesquisadoras e lideranças que têm objetivos em comuns para a educação, que é a luta por uma educação antirracista. Ao pensarmos nas possibilidades educativas nas comunidades quilombolas, trazemos experiências vividas no campo da educação antirracista que contribuem para reflexão um pouco mais aprofundada sobre o que observamos e desejamos enquanto educadores/as em uma comunidade tradicional. O próprio conceito de "Comunidades Tradicionais" é colocado em xeque porque reflete a expansão rizomática diversa e difusa com que este conceito se expande nos amplos campos teóricos dos estudos étnico raciais.

Nessa compreensão é possível entender que trabalhar a Educação Quilombola se refere às diferentes formas que, considerando os contextos da Educação, ampla, diversa, garantida pela LDBN 9394/96 (BRASIL, 1996) e que compreendam currículos que contextualizem e referenciem a história da população afro-brasileira nos territórios devidamente reconhecidos pelos sujeitos que lá estão, pela tradição familiar quilombola independente da força da lei. Precisamos dialogar sobre a Educação Escolar Quilombola e, a partir das práticas conceituais narradas pelos sujeitos, pensar a construção de práticas pedagógicas de acordo com o Plano Nacional de Implementação das Diretrizes Curriculares Nacionais para a Educação das Relações Étnico-Raciais e para o Ensino de História e Cultura Afro-Brasileira e Africana, que nos aponta que ela deve ser

[...] desenvolvida em unidades educacionais inscritas em suas terras e culturas, requerendo pedagogia própria em respeito à especificidade étnicocultural de cada comunidade e formação específica de seu quadro docente, observados os princípios constitucionais, a base nacional comum e os 
princípios que orientam a Educação Básica brasileira [...] (BRASIL, 2013, p. 59).

Em 2019, o Núcleo de Estudos Afro-Brasileiros (NEAB) iniciou um curso de Formação, no contexto da Educação Quilombola em parceria com a Comissão de Estudos Afro-Brasileiros do Município, Secretaria de Cultura e Programa de PósGraduação de Mestrado Profissional em Educação da UFES. A necessidade de se fazer a escuta ativa das crianças quilombolas surgiu no curso de formação de professoras/es quilombolas, que atende a um público de 35 pessoas, entre professoras/es e lideranças quilombolas, realizado em duas etapas, a primeira de caráter formativo e a segunda etapa de caráter investigativo, com a metodologia da pesquisa-ação na comunidade de Linharinho - Conceição da Barra. Essa comunidade está localizada no baixo curso do Córrego São Domingo, vizinho à localidade de Santana, cortada pela estrada de Conceição da Barra até à Vila de Itaúnas.

Os percursos considerados para essa formação visam colaborar com a práxis comunitária dos sujeitos no território, mapeando os desafios da implementação das Leis 10.639/2003 (BRASIL, 2003a) e 11.645/2008 (BRASIL, 2008) na Educação Quilombola. Além disso pretendem incentivar o uso de recursos e suportes pedagógicos que ampliem as possibilidades pedagógicas com a comunidade, tais como o uso das sequências didáticas, quadrinhos, tirinhas e literaturas africanas e afrobrasileira, proporcionando o entrelaçar dessas histórias com as contadas pelos sujeitos da comunidade.

Andrade (2007) argumenta sobre o sentido de comunidade a partir hermenêutica do "sujeito da compreensão" de Santos (2007, 2010), em seus pressupostos sobre uma "comunidade interpretativa" que busca explicar o sentido comunidade a partir da perspectiva da mediação, baseando-se no diálogo, na leitura e 
na tradução da construção do comum no espaço e no tempo. A roda, Figura 1, trouxe esse sentido de comunidade para a formação de professoras/es e lideranças.

Ali iniciamos os primeiros diálogos de afinidades, buscando entrelaçar saberes, construir esse sentido de pertencimento e segurança, para discutirmos os problemas comuns de nosso cotidiano quilombola. Ouvimos muitos relatos pertinentes e trouxemos alguns para a escrita deste texto, assim, ilustrarão parte do que estamos construindo. A partir dos encontros, a coordenadora local do Centro de Estudos AfroBrasileiros (CEAFRO) convidou uma professora de Linharinho para que trouxesse como relato as narrativas de seus estudantes.

O intuito de escrever sobre a produção de dados nos espaçostempos das pesquisas realizadas nas comunidades quilombolas vem exatamente nos desafiar a repensarmos quais são os pontos articulados e as tensões do campo empírico que nos levaram ao reconhecimento da importância do ato de narrar experiências - trocas de saberes. As narrativas trazem em si a dimensão de utilidade e carregam o peso do aconselhamento. Benjamin (1994) esclarece que não é qualquer um que aconselha. Para tanto, é preciso, antes de tudo, fazer a ligação entre as experiências do narrador e a história que está sendo narrada, na medida em que se verbaliza a situação.

Dessa forma, Benjamin (1994) atenta para o fato de que as ações da experiência são pouco relatadas, pois existe uma grande dificuldade e até mesmo resistência por parte dos pesquisadores em Ciências Sociais em aceitá-las como procedimento metodológico. O autor complementa afirmando que a experiência que passa de pessoa para pessoa é a fonte a que recorrem todos os narradores e, entre as narrativas, as melhores são as que menos se distinguem das histórias orais contadas pelos inúmeros narradores anônimos. Entrelaçando essas narrativas, procuramos fazer a ponte entre os relatos das experiências como "construção" de conhecimento. São essas narrativas e ações que contribuem para o entendimento de como se constituem as redes de conhecimentos no cotidiano. 


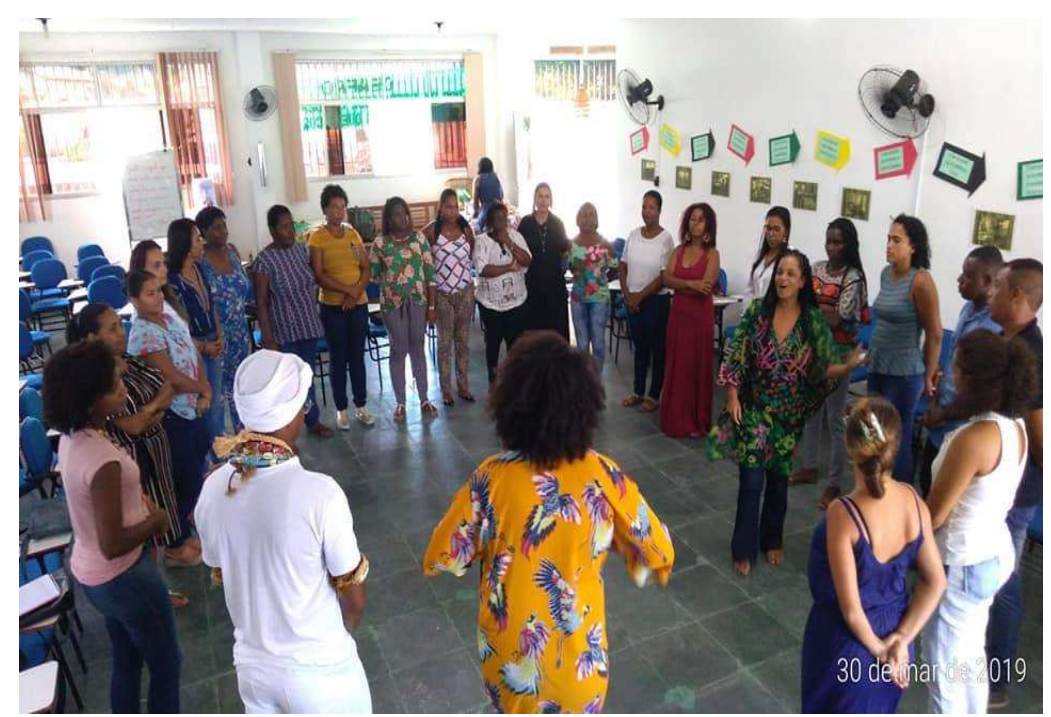

Figura 1 - Formação de lideranças e professoras/es quilombolas. Fonte: Acervo das autoras - maio de 2019.

Alves (2002) nos faz refletir sobre as tensões atuais que, no século XX, levaram a questionar as diferentes formas de "construir" conhecimento. Aponta, ainda, que as transformações ocorridas no mundo do trabalho, as exigências das novas ciências de ponta - pautadas na informática e comunicação, em geral - foram se ampliando e constituindo novos campos de conhecimento, impondo a expansão dos saberes concebidos e vividos de forma não-linear, mas rizomática: em rede. Essas questões estão postas nas salas multisseriadas da comunidade. As crianças têm acesso bastante limitado ao celular, aos joguinhos de computador, ou seja, à múltiplas mídias, estas tecnologias ainda dialogam pouco em um território praticamente sem recursos, sem investimento, principalmente na educação escolarizada.

Portanto, é urgente pautarmos o diálogo para que nós professores e professoras, que atuam diretamente nessa diversidade de situações possamos partilhar alternativas, esse é o sentido da formação - compartilhar. E enfim, organizar algumas atividades baseadas nas ações práticas e teóricas de alguns módulos do curso. Para tal, algumas ações/oficinas foram planejadas para qualificar esses momentos. 
Assim, nasceu um questionamento entre a formação de professoras, com a seguinte indagação: Se ouviremos as narrativas das lideranças e professoras/es da escola, como traremos as narrativas das crianças? Desse modo, o trabalho de escuta das narrativas, utilizando os recursos de entrevistas escritas, desenhos e roda de conversa foi desenvolvido com a turma multisseriada (de 1으 ao 5으 ano) da escola Municipal "Linhares", na comunidade de Linharinho no Município de Conceição da Barra - ES.

A escolha em utilizar as narrativas se faz sob influências teóricas e proposições de Benjamin (1994 p. 37), que considera que a "arte" de contar histórias, vivências e acontecimento é infinito, "pois um acontecimento vivido é finito, tendo em vista que o acontecimento lembrado é sem limites, porque é apenas uma chave para tudo o que veio antes e depois". Mesmo não adentrando ao debate do período colonial e pós escravidão, o que tomaria um longo debate, gostaríamos de registrar que a característica dessa comunidade remanescente de quilombolas traz histórias que remontam o passado/período escravocrata, logo, as narrativas circulam no modo de ser, da luta pela terra, na maneira de viver a religiosidade e relações sociais. Não obstante, as narrativas das histórias também trazem as marcas do racismo, demarcando esse "antes" e o resultado desse "antes" marca as vivências dessa comunidade na atualidade.

Benjamin (1994) destaca em seus ensaios que a palavra narrativa é repleta de sentidos e significados e carrega um significado histórico sociológico, pois ela se baseia nas experiências de toda uma vida e de uma vida de todos. As falas e experiências dos adultos foram colhidas em entrevistas variadas, utilizando diversas fontes, reportagens, entrevistas e conversas pessoais/ou por telefone e recursos via celular.

Para as ações com as crianças, os recursos metodológicos utilizados foram estimulados nas atividades de sala. Ao planejar as ações, selecionamos os recursos e os suportes no formato de literaturas infantis afro-brasileiras para fomentar as perguntas e debates geradores. Nas atividades escritas e orais utilizamos as narrativas, 
desenhos e textos nos quais os estudantes trouxeram suas percepções e vivências. Algumas questões centrais foram privilegiadas, tal como associar as histórias apresentadas nas literaturas ao contexto da comunidade, e enfim adentrar na comunidade, quais percepções de espaços-tempos, história, desejos, situações de racismo e modos de viver as festas na comunidade.

Partindo dessas vozes, expomos neste artigo a reflexão das pautas que tratam das questões pedagógicas ligadas às relações étnicas raciais envolvendo as crianças quilombolas. Este texto terá seu suporte teórico considerando a sociologia da Infância, priorizando os marcos legais e especificidades da Educação Quilombola. Destacamos, inicialmente, que todos os/as estudantes envolvidos/as são crianças remanescentes de quilombos, e segundo o artigo 2o do decreto 4.887 de 2003 (BRASIL, 2003b) que nos aponta que

Consideram-se remanescentes das comunidades dos quilombos, para os fins deste Decreto, os grupos étnico-raciais, segundo critérios de autoatribuição, com trajetória histórica própria, dotados de relações territoriais específicas, com presunção de ancestralidade negra relacionada com a resistência à opressão histórica sofrida (BRASIL, 2003b).

De certo modo, os critérios de auto atribuição estão relacionados ao processo de identificação cultural. Não há como pensar a infância quilombola baseando-se na educação tradicional e urbana, visto que esta não dá conta das especificidades e complexidade que envolvem a modalidade da educação quilombola. São essas especificidades que permeiam as infâncias quilombolas. E nessa linha teórica, acreditamos no modelo histórico-cultural, no qual Rego (2002, p. 20) afirma que:

Os traços de cada ser humano estão intimamente relacionados ao aprendizado, à apropriação do legado do seu grupo cultural. 0 comportamento e a capacidade cognitiva de um determinado indivíduo dependerão de suas experiências, de sua história educativa, que, por sua vez, sempre terão relações com as características do grupo social e da época em que ele se insere. Assim, a singularidade de cada indivíduo não resulta de fatos isolados, mas da multiplicidade de influências que recaem sobre o sujeito no curso do seu desenvolvimento. 
E ao pensarmos essa comunidade, percebe-se sua singularidade na história, suas influências que permeiam as tradições. Em uma das atividades de sala, percebemos que 16 das 17 crianças se autodeclararam negras, possuíam suas tradições e modo de viver diferenciado e ainda vivem os vários entraves políticos, sociais e econômicos pela luta pelo território, direito à terra e educação de qualidade.

\section{A comunidade de Linharinho - Conceição da Barra-ES}

A comunidade de Linharinho está situada onde se localizava a propriedade latifundiária de Dona Rita Maria Conceição Gomes da Cunha. Nesse local, conta-se que um negro escravizado, conhecido como Negro Rugério, em época de escravidão, fugiu dos maus tratos, se abrigou nos limites da própria Fazenda, a princípio com mais trinta negros/as, onde deu origem ao quilombo. Ali permaneceu e fez acordos com Sra. Dona Rita, com a qual comercializava a farinha de mandioca e seus derivados (do quilombo), em troca desse acordo de não entregar os negros e negras que moravam ao redor da sua fazenda.

No entanto, após a morte da latifundiária, o desmonte do acordo se deu com violência militar e, em 1881, o grande ataque ao território desencadeou na morte da liderança do quilombo, o negro Rugério e demais negros/as. A área chegou a ser habitada por cerca de 10 mil famílias quilombolas até o final da década de 1960 . Com a chegada da Aracruz Celulose (atual FIBRIA) esse número de famílias foi reduzindo para em média mil famílias. Atualmente, apenas oitenta famílias resistem em pequenas comunidades em meio aos eucaliptos da empresa. As lideranças de Linharinho relatam que seus ancestrais pertenciam aos povos africanos de tradição nagô, dos quais herdaram elementos culturais relacionados à língua Yorubá.

A região está localizada no baixo curso do Córrego São Domingo, vizinho à localidade de Santana, nela, corta-se uma estrada de Conceição da Barra até à Vila de 
Itaúnas. Essa comunidade é a primeira a ser reconhecida no Estado do Espírito Santo. Sua economia se baseia no cultivo da mandioca e na produção de farinha e outros derivados, além dos artesanatos, sendo esses saberes herdados direto da ancestralidade africana.

Hoje com sua paisagem bastante alterada, a comunidade enfrenta desafios socioambientais que fragilizam toda sua a estrutura. As questões envolvem desde a concepção de escola do campo, à assistência à saúde, preservação do meio ambiente, desafio da agricultura, desaparecimento das nascentes entre outros.

Segundo, Romano (2008. p. 32)

O rio São Mateus (antes, rio Cricaré) era uma importante via de comercialização no século XVIII. O porto se destacava pela venda de farinha de mandioca e por nele desembarcarem grande parte dos negros que vieram para o Brasil, atraindo interessados de várias regiões brasileiras à procura de mão-de-obra para as fazendas. Foi aí que desembarcaram também os antigos protagonistas e fundadores do que é hoje a Comunidade de Linharinho, bem como comunidades vizinhas que compuseram o povoado de Sant'Ana no Quilombo do Morro.

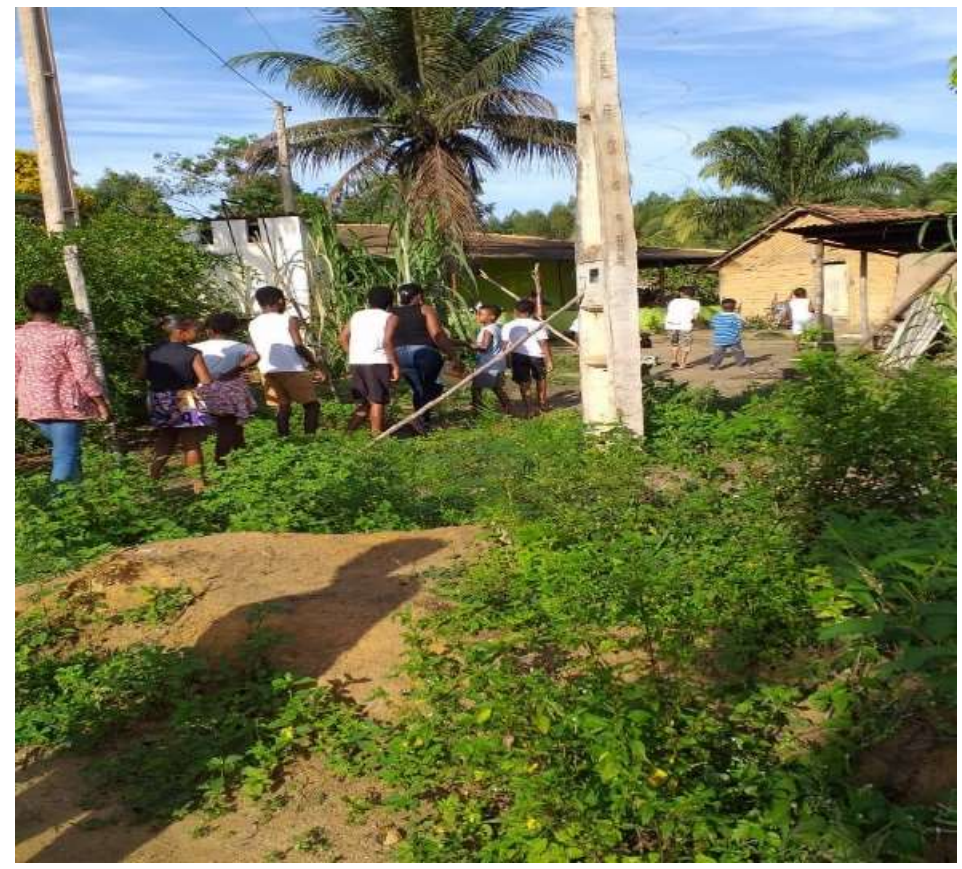

Figura 2 - Crianças no momento de pesquisa da vegetação na comunidade. Fonte: Acervo das autoras-2019. 
O Território de Linharinho é um território de luta e constantemente violentado em seus direitos. Em 2018, a Coordenação Nacional de Articulação das Comunidades Negras Rurais Quilombolas CONAC (CONAQ) apresentou os dados que confirmam essas expectativas. O resultado da pesquisa intitulada "Racismo e Violência contra os quilombos no Brasil" apontou diversos tipos de violências contra a população quilombola de Linharinho. Para mapear as violências, a CONAQ, utilizou 6 categorias: Especulação imobiliária, Latifúndios, Megaprojetos Socioambientais, Racismo Estrutural, sem informações e outros. Nessa amostra, apontou que $32,8 \%$ das violências das quais as comunidades eram vítimas, estavam configuradas em 1의 lugar, de ordem do racismo estrutural, em 2 ㅇ lugar, com 20,8\% a ordem dos latifundiários, e 3ㅇ lugar os problemas com os megaprojetos socioambientais. O infográfico - CONAQ (2018, p. 33) está na Figura 3.

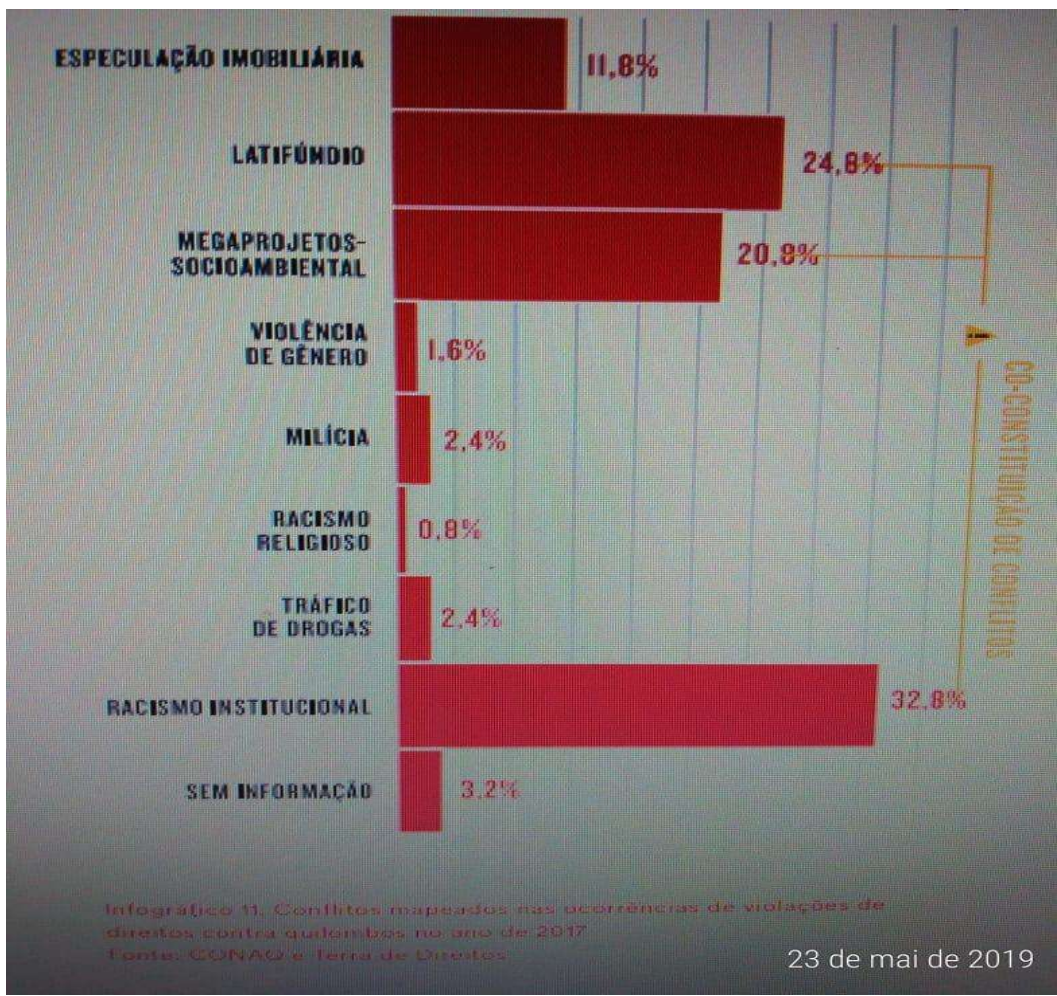

Figura 3 - Infográfico. Conflitos mapeados nas ocorrências de violações de direitos contra quilombos no ano de 2017.

Fonte: CONAQ e Terra de Direitos. 


\section{Sobre o olhar e narrativas de uma ex-professora: a escola EMEF LINHARES}

A história da escola é contada pela professora aposentada, a Dona Benedita Cassiano, nascida em 1958, residente da comunidade quilombola de Linharinho, que lecionou na escola durante 30 anos. Ela relata que a escola surgiu na década de 1920 e os estudantes que moravam na comunidade precisavam ir para o povoado de Santana para estudar. Destaca que naquela época não tinham transporte e as pessoas demoravam horas para chegar até a escola rural. Segundo ela, uma das alunas era a Dona Oscarina (uma antiga moradora da comunidade), que estava se preparando para dar aula nessa escola, mas por motivos políticos foi substituída por outra pessoa indicada pelo prefeito, que morava na Vila de Conceição da Barra. Nessa escola, passaram várias professoras que a comunidade se lembra: Dona Léia, Dona Dalci, Dona Noêmia e antes destas, outras mais antigas. A escola era conhecida como Escola Singular Linhares e ficava situada no terreno Sr. Leovegildo, um velho morador da comunidade.

Ela afirma que a escola era espaçosa, tinha quatro banheiros, uma cozinha, uma sala grande e outra pequena, dois quartos onde as professoras dormiam, um depósito para merenda e uma área de lazer. Na escola, o fogão era à lenha, os estudantes e familiares ajudavam com a lenha, as cadeiras eram de tábuas e pés de ferro, cabendo três crianças por carteira. E nesse tempo, as crianças caminhavam quase duas horas para chegar até a escola, pois alguns moravam há 8km de distância.

Na década de 1980, a escola aderiu ao Movimento Brasileiro de Alfabetização (MOBRAL), a faixa etária era para quem tivesse acima de 18 anos, a alfabetização era multisseriada - salas que recebem estudantes de diferentes idades e níveis - e, em 1986, a propriedade foi vendida para os Srs. Vivaldo e Senhor Esio. Um deles não aceitou a escola perto de sua residência, cedeu outro local para ela, localizado perto da igreja e da estrada. Segundo ela, a antiga escola virou galpão da fazenda e outra 
escola foi construída, mas segundo a comunidade, ficou muito pequena e tem seus espaços inadequados. Atualmente, a escola atende estudantes da Educação infantil e Séries iniciais, precisando de melhorias para atender à comunidade. A sala multisseriada tem 17 alunos/as, foi inaugurada em 2010, e sua professora é moradora da comunidade. Partindo da escuta ativa e dessa narrativa que apresenta a história da escola, apresentamos a seguir a reflexão das pautas que dizem respeito às vivências e experimentações das crianças quilombolas.

\section{Sobre educação quilombola e suas narrativas}

As crianças inseridas nesse contexto social apresentam nos desenhos o que vivem, o que sentem, as realidades vividas mostram a resistência e auto-organização como condição do existir. Numa atividade de sala de aula, foi solicitado que falassem /ou/ desenhassem a representação de sua comunidade. O desenho da Figura 4 revela a riqueza de detalhes que envolve o conhecimento dessas crianças sobre as pessoas que vivem no território quilombola de Linharinho. Ousamos dizer que a imagem se configura numa atividade na qual o estudante "cartografou" o cotidiano, incorporando um conjunto de fatores da tradição local realçando a configuração de moradia, a base, as casas compreendidas como núcleos de referências, lideranças, ilustrando a estrada e do outro lado da comunidade uma fazenda.

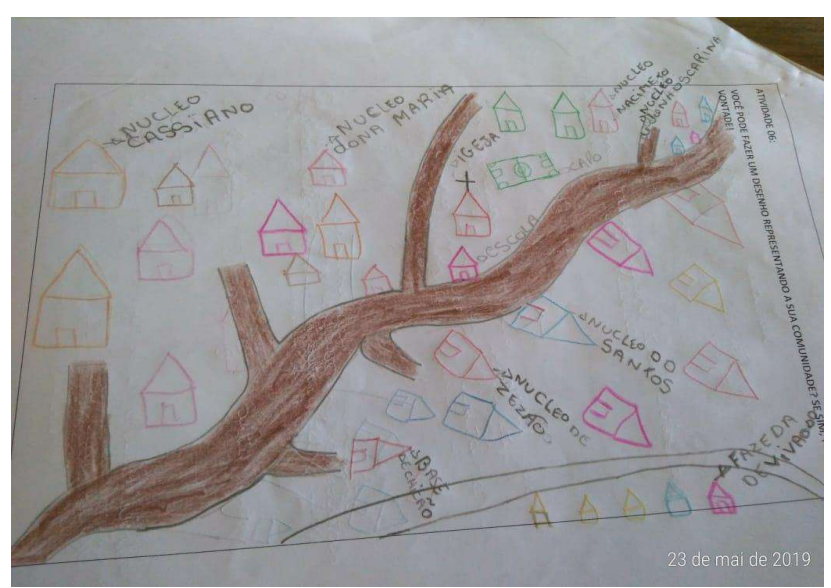

Figura 4 - Representação da comunidade-Linharinho.

Fonte: Desenho do estudante Gabriel B. dos Santos. 5ㅇano da sala multisseriada. 
Ao solicitar que defina a sua comunidade em uma frase, o mesmo estudante responde, falando dos rios, trazendo algumas memórias da comunidade, das vivências e fazeres no rio São Domingues.

\begin{abstract}
A minha comunidade é muito importante, porque tem muitas coisas, tem "histórica": o quilombo, o rio São Domingo.

O rio São Domingo era muito limpo, que todo mundo tomava banho, lavava roupa, lavava vasilha, hoje está vazio, está de mato, está feio, hoje ninguém toma banho [...] (Gabriel B. Santos - 12 anos).
\end{abstract}

Essa narrativa diz muito sobre a seca que as comunidades vivem nas estações quentes do ano, nos diz sobre os problemas ambientais que a comunidade enfrenta, o histórico das problemáticas das comunidades quilombolas no Brasil, que apresentam categorias de violências sofridas que se assimilam. Destaca-se a monocultura do eucalipto, as grandes empresas que causam danos às comunidades e todo ecossistema, caracterizado por índices de racismo estrutural.

Desse modo, observa-se que numa pequena narrativa de uma criança, apresenta-se a memória coletiva de um rio que um dia foi e hoje já não é mais. O rio que tomavam banho, lavava vasilha etc., um rio-vida e sem esse rio restam-Ihe as memórias e junto a essas memórias, as violências sofridas no contexto de ordem capitalista e do racismo estrutural que se apresenta ferozmente contra o modo de ser e viver quilombola. Essa violência está caracterizada nos apontamentos da CONAQ (2018, p. 33).

\begin{abstract}
A contaminação das águas e dos rios de um quilombo devido ao uso pernicioso de agrotóxicos pelo agronegócio ou por latifundiários vizinhos, situação emblemática do cruzamento de ameaças em uma dada situação, acarreta não apenas ameaça à saúde das pessoas e danos à fauna e à flora, mas também risco de desagregação social, cultural e econômica do próprio território.
\end{abstract}

Sabendo dos princípios que regem a educação quilombola, não poderíamos desconsiderar as vivências dessas crianças que estão imbricadas no mundo adulto da 
comunidade que se configura dentro das relações raciais, sociais e econômicas. Por isso, a perspectiva deste trabalho é buscar ações para o desafio de se pensar a educação quilombola como enfrentamento ao racismo estrutural. A Lei de Diretrizes e Base da Educação 9304/96 LDB (BRASIL, 1996), em consonância com as Diretrizes Curriculares Gerais para a Educação Básica, CNE/CEB 04/2010 (BRASIL, 2010) estabelecem as Diretrizes Curriculares Nacionais para a Educação Escolar Quilombola na Educação Básica, que, sob a forma de Resolução, traz o texto a seguir.

§ 1ㅇ A Educação Escolar Quilombola na Educação Básica:

I - Organiza principalmente o ensino ministrado nas instituições educacionais fundamentando-se, informando-se e alimentando-se:

1. da memória coletiva;

2. das línguas reminiscentes;

3. dos marcos civilizatórios;

4. das práticas culturais;

5. das tecnologias e formas de produção do trabalho;

6. dos acervos e repertórios orais;

7. dos festejos, usos, tradições e demais elementos que conformam o patrimônio cultural das comunidades de todo o país;

8. da territorialidade.

Não podemos desconsiderar todo o processo histórico que caracteriza os quilombos do território do Brasil, no qual se percebe que as comunidades têm sua construção baseada em estratégias e lutas contra o racismo, direito à vida, ao território e políticas públicas como direito à educação, saúde e trabalho entre outros direitos básicos.

Em 2014, o Conselho Municipal de Educação de Conceição da Barra - ES aprovou a resolução que regulamenta a Educação Quilombola, que está sendo desenvolvida nas comunidades quilombolas, em conformidade com o Plano Municipal de Educação (PME), aprovado em 2015, e em consonância com as Diretrizes Curriculares. 


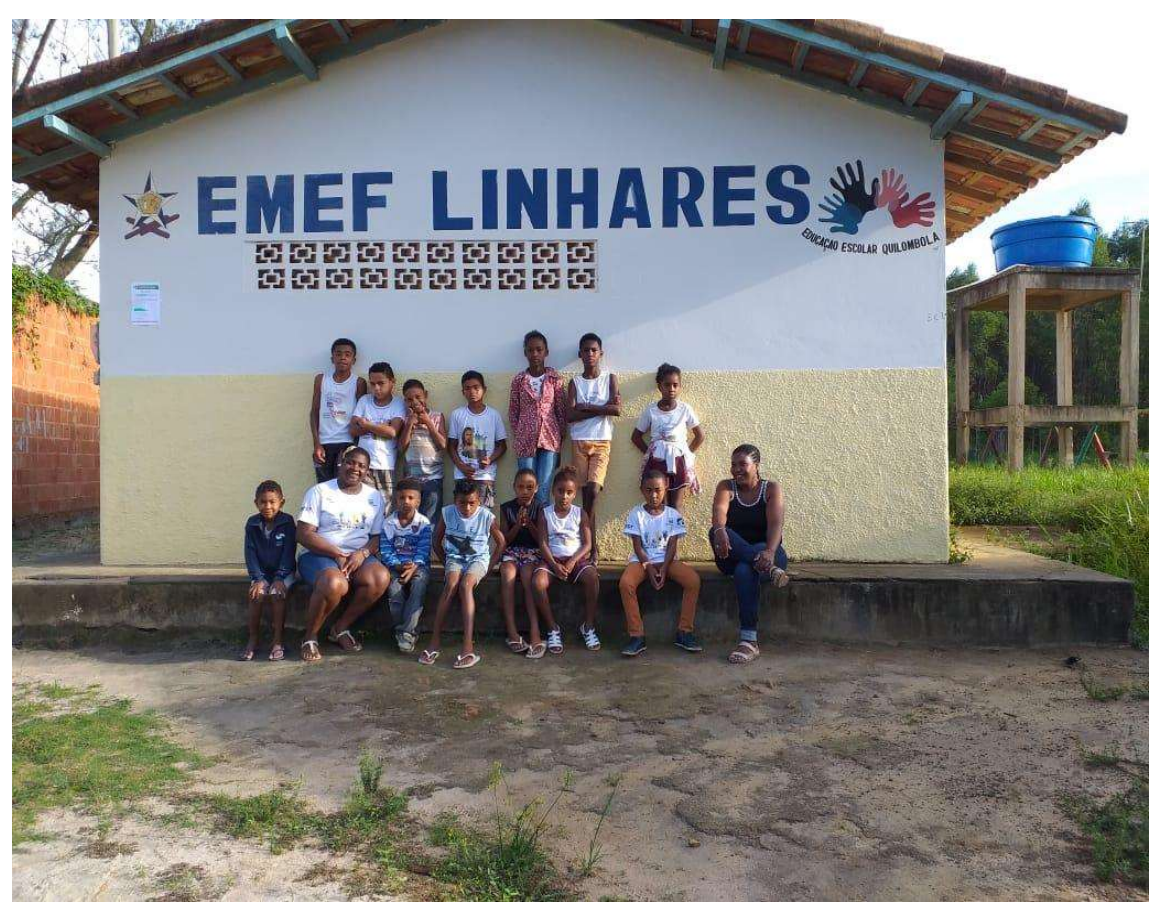

Figura 5 - As crianças quilombolas, a escola e as professoras Genilda e Sidineide. Fonte: Acervo das autoras - maio de 2019.

Para tanto, o texto nos traz alguns princípios a serem observados.

Respeito e reconhecimento da história e da cultura afro-brasileira como elementos estruturantes do processo civilizatório nacional; valorização da diversidade étnico-racial, religiosa, ambiental e sexual; conhecimento dos processos históricos de luta pela regulamentação dos territórios tradicionais dos povos quilombolas; o fortalecimento de uma relação dialógica entre escola e comunidade; assegurar que a atividade docente das escolas quilombolas seja exercida preferencialmente por professoras/es oriundas/os da própria comunidade; e demais princípios de mesma ordem de relevância.

\section{As narrativas das crianças quilombolas}

Kramer (2009) apresenta a necessidade de valorizar a interação com os discursos e narrativas das crianças, com suas experiências de vida construídas nos encontros e nos conflitos. A maioria das crianças da sala se autodeclaram negros/as, apenas um se declarou pardo. Gostam de brincar de bola, dominó, amarelinha, bambolê, pular corda, jogo de memória, pique-esconde, pique bandeira, andar a 
cavalo, morto-vivo, soltar pipa, corre e rola. O local que eles mais gostam na comunidade é o campo de futebol, este se apresenta como única alternativa.

Selecionamos algumas narrativas coletadas, nessa escrita optamos em não identificar os nomes das crianças, utilizaremos apenas as letras iniciais. Numa atividade de sala de aula, utilizando o tema sobre racismo, a professora Genilda perguntou se alguém já o vivenciou. E obteve alguns comentários/resposta.

Eu nunca sofri, mas vi minha colega chamar outra colega de "cabelo de pico (L. 14 anos).

Já me xingaram por conta do meu cabelo (T. 8 anos).

Já me chamaram de macaca. Eu não gostei e fiquei quieta (T. 7 anos).

Já me chamaram de cabelo de pico (E. 7 anos).

Sobre essas falas, gostaríamos de debruçar o diálogo, pois elas são rotineiras e estão dentro do campo discursivo da sociedade, moldadas nas teorias racistas. E as crianças aprendem e repetem as atitudes e discursos do mundo adulto. Em quase todas as falas, principalmente quando ouvimos as meninas, o enredo se repete, o ataque que vem nas relações infantis sempre destaca o cabelo como centro para o ato racista, logo, as falas/xingamentos serão: cabelo de pico, cabelo de bombril, pixaim, entre outros, infelizmente um dado recorrente em toda sociedade que utiliza as características diversas da negritude para desqualificar o outro enquanto sujeitos. Sabendo de todo contexto histórico do racismo, Munanga (2003, p. 8) nos aponta que:

O racismo é uma crença na existência das raças naturalmente hierarquizadas pela relação intrínseca entre o físico e o moral, o físico e o intelecto, o físico e o cultural. O racista cria a raça no sentido sociológico, ou seja, a raça no imaginário do racista não é exclusivamente um grupo definido pelos traços físicos. A raça na cabeça dele é um grupo social com traços culturais, linguísticos, religiosos etc. que ele considera naturalmente inferiores ao grupo à qual ele pertence. De outro modo, o racismo é essa tendência que consiste em considerar que as características intelectuais e morais de um dado grupo são consequências diretas de suas características físicas ou biológicas. 
Segundo Orlandi (1997, p. 43) uma formação discursiva, "Se define como aquilo que em uma formação ideológica dada, ou seja, a partir de uma posição dada em uma conjuntura dada - determina o que pode e deve ser dito". Nota-se que o sentido de uma fala dita é definido por meio de uma ideologia, nesse caso, a ideologia fundamentada no discurso racista. Em sua pesquisa, Gaudio $(2015$, p. 13) apresenta a seguinte reflexão.

[...] as crianças demonstraram através das relações efetivadas com seus pares que a dimensão étnico-racial esteve sempre associada aos aspectos corporais de gênero, desempenho, forma, cor e estatura. Em suas brincadeiras, ações e diálogos as crianças demonstravam suas concepções acerca da categoria étnico-racial, reproduzindo de modo próprio muitos dos preconceitos e estereótipos existentes no contexto social em que vivenciam.

Ou seja, numa relação dialética homem/sociedade, a criança pequena tida como novo membro, interioriza o mundo que lhe é apresentado. Essa apresentação é definida pelo comportamento adulto e foi construída antes da sua chegada ou existência, assim, ela aprende todos os valores, opiniões e modo que a sociedade atua. Outro ponto a se considerar na narrativa da estudante T, é sobre o silenciamento, quando a menina diz que "ficou quieta", devemos considerar que o silêncio tem vários sentidos.

Cavalleiro (2012, p. 59) nos aponta que: "O silêncio da criança diante dos outros demonstra a sua fragilidade em situação humilhante, imposta pelo amigo. Sinaliza o quanto ela não domina seu direito a defesa". A pesquisadora ressalta que os problemas se acumulam devido à ausência de informações a um determinado conhecimento, geralmente o silêncio, o ficar calado se revela estratégico para evitar o conflito étnico. E para ela, é improvável que uma criança que é hostilizada consiga construir uma identidade positiva.

É no fazer pedagógico junto à comunidade que as professoras criam estratégias de valorização das raízes africanas que compõem a comunidade, apresentam histórias, 
contos e cantigas de valorização do povo negro. Para essas ações foram pensadas as histórias em que as crianças pudessem enxergar as suas matrizes culturais, tendo representatividade nas imagens, nos/as personagens e assim se autoafirmarem a partir de uma visão sem estereótipos, sem exageros, ou seja, histórias que revelassem alguma aproximação das culturas africanas às culturas afro-brasileiras.

Numa atividade, a professora contou a história do livro: "As panquecas de Mama Panya", de autoria de Mary e Rich Chamberlin, o enredo mostrava uma mulher negra, que morava num vilarejo no Quênia, a Mama Panya, que resolveu fazer panquecas e foi ao mercado com o filho Adika para comprar farinha e temperos. No trajeto, o menino não se conteve e convidou para o jantar todos os/os amigos/as que encontrou. Mama Panya tinha poucas moedas na bolsa, mas o que poderia ser um problema se transformou numa manifestação de amizade, união, compartilhamentos, mostrando alguns valores necessários na convivência moldada em solidariedade e alegria. A professora e coordenadora da turma relataram esses momentos:

Primeiro momento: Apresentamos o livro e contamos a história: As panquecas de Mama Panya. Motivamos e estimulamos com perguntas referentes e trouxemos para outra realidade do cotidiano, pois na história fala da panqueca e na comunidade falamos do beiju, e outros produtos oriundos da mandioca. Eles foram falando os tipos de beijus e outras coisas. E neste dia ficamos sabendo que na Comunidade do Linharinho tem um pé de Baobá. Então foi marcado para irmos ao local no outro dia. Após isso entregamos uma atividade pedindo para narrarem o que ouviram $e$ dialogaram sobre a história (Profa. Sidineide).

As crianças apresentaram algumas semelhanças entre a literatura apresentada e realidade da comunidade tal como: a panqueca citada na literatura e o alimento (Beiju/Bijú) da comunidade em que vivem. Para se fazer o "beiju", muitas pessoas são envolvidas, não é um trabalho de grande escala, em cadeia produtiva com equipamentos modernos, mas são receitas guardadas dentro da ancestralidade dos que por aquele território passaram e esses saberes permanecem vivos nas memórias 
da comunidade. O processo para fazer o beiju envolve a todos, do plantio da mandioca até sua comercialização. E nesse percurso, os saberes de cada um é doado, compartilhado, para o fim comum que é a busca por dignidade e valorização dos conhecimentos ancestrais.

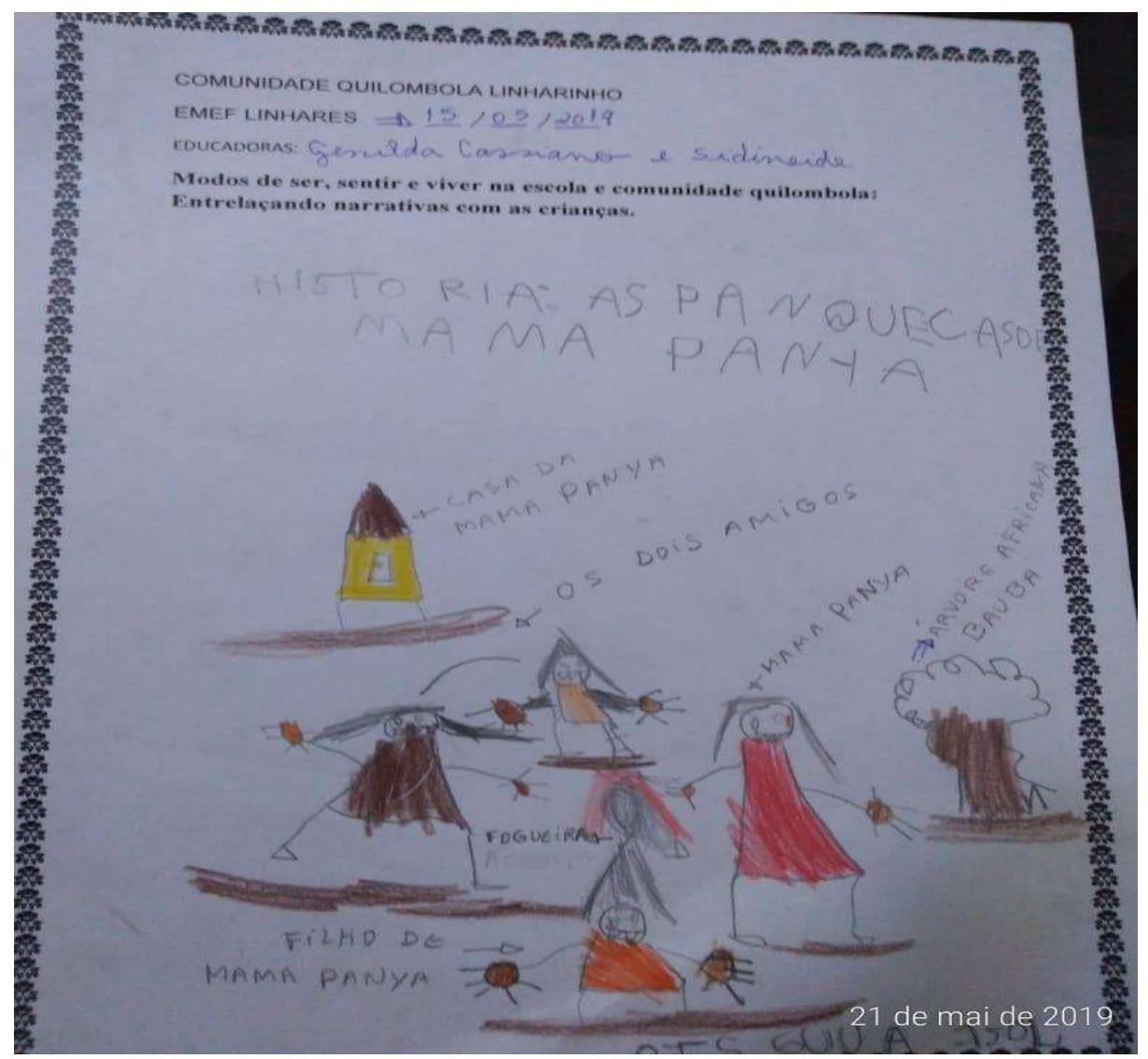

Figura 6 - Atividade de releitura do livro: As panquecas de Mama Panya de estudante do 10 ano da sala multisseriada Fonte: Acervo das autoras - maio de 2019.

Outra correlação da história é que, no livro, a história se perpassa meio a aldeia de comunidade queniana, com muitos Baobás no trajeto em que os personagens fazem até o mercado para comprar os ingredientes. Isso fez com que as crianças e professoras lembrassem que eles também têm um pé de baobá jovem na comunidade, e então fizeram juntos o trajeto. No caminho, a professora destacou: "eles foram lembrando 
da história contada no livro e foi associando às espécies de animais às espécies de animais existentes na Comunidade antigamente e atualmente". Na sala de aula, as crianças exploraram essa narrativa apresentada pela professora e fizeram atividades correlatas, assim, um universo de linguagens entrelaçadas surgiram, dando significado às aulas e entrelaçando histórias.

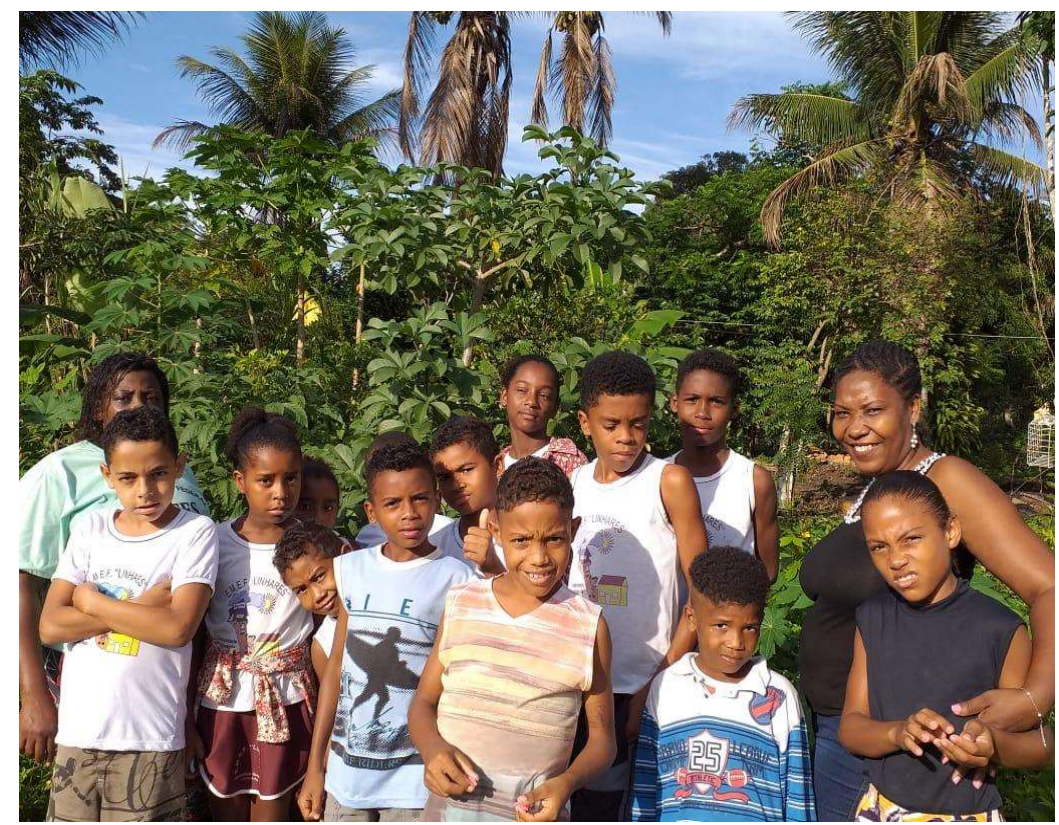

Figura 7 - Baobá-jovem plantado na comunidade e visita das crianças. Fonte: Acervo das autoras- maio de 2019.

\section{Participação em festas e religiosidades na comunidade}

As crianças da comunidade gostam de participar das festas da comunidade, falam da festa da mesa e jongo de Santa Bárbara, evento que apresentamos no formato de entrevista trazendo a narrativa de uma liderança, a Dona Miúda, que afirmou que

A religião daqui era o quê? Era candomblé, era ladainha, era ofício de Nossa Senhora. [...]. Tudo coisa de povo africano. [...] Aqui no Sapê do Norte, os negros tinham dois tipos de trabalho religioso: o candomblé e o camocite. [...]. Depois, de tanto ser perseguidos por autoridades, polícia e padres, esses negros que vieram da África, esses nagores (nagôs) africanos, tiveram que 
colocar outros nomes de religião: Mesa de Santa Bárbara, Mesa de Santa Maria e Mesa de São Cosme e Damião. Nesse Sapê do Norte, o povo tinha essas três mesas como tradição. Foi de, me parece, de 1886 pra lá, eles só viviam nessa religião. Foi nas proximidades de 1980 que os padres começaram a perturbar, o Bispo de Vitória mandava os padres vir a esse povo, quinze dias nesse Sapê do Norte, pra ver como estava a religião desse povo. E aqui eu acho que ficou a família da Aurora Deolinda da Conceição, minha tia, minha mãe também, que eram entendidas dessas coisas. $O$ Joaquim Felipe da Vitória (bisavô de Miúda) também era da mesa de Santa Bárbara que tinha aqui. [...] Hoje, o povo que sabia mesmo da religião foi tudo embora. A gente ainda sabe um pouquinho da coisa do ritual da Mesa, mas tudo bem. "E nós temos aqui na comunidade, que é a comunidade Santa Bárbara, porque a religião que mexia aqui [...] era o candomblé. Aí, através de padres, com esses donos de poderes, prendeu muitos negros pela sua religião. A gente quer de volta tudo isso. (Dona Miúda - entrevista concedida ao site do projeto Kizoomba).

A comunidade apresenta em suas narrativas que a cabula era um culto afro de origem banto que existiu no norte do estado do Espírito Santo, até a década de 1970. O culto era composto por três mesas de Santo: mesa de Santa Maria, mesa de Santa Bárbara e mesa de Cosme e Damião. As mesas de Santa Bárbara e Cosme Damião ainda existem nas comunidades quilombolas do Sapê do Norte - grande território que se encontra em Linharinho - mas os rituais conhecidos como a cabula e mesa de Santa Maria não existem mais na comunidade aqui referendada, essas mesas tinham os rituais realizados em meio às matas. As professoras da comunidade relatam que como esses conhecimentos não foram passados, a tendência foi desaparecer. "Essas mesas eram muito secretas, não era passado para nós. As pessoas foram morrendo e levando com elas esses conhecimentos" (Profa. Genilda, 2019).

As crianças apontam em suas narrativas escritas e por meio dos desenhos que a melhor festa é o jongo de Santa Bárbara, falam que é alegre, que participam com suas famílias, algumas dizem que não participam pelo distanciamento de suas casas e, por não terem transporte dentro da comunidade, eles deixam de ir à festa. $\mathrm{O}$ que 
dizem as crianças quando perguntamos sobre as festas que frequentam e que mais gostam na comunidade?

Eu gosto das festas, vou pro carnaval, festa de Santa Bárbara, fui pra Alegre, no encontro de jongueiros, vou pro divino Espírito Santo e muitas festas ( $P$. 10 anos).

Eu costumo ir às festas de Santa Bárbara com minha família, é muito legal. [...] Gosto de ir às festas da escola Quando tem forró na Barra, eu também vou (M. 8 anos).

Eu gosto de forró, aniversários e festa da padroeira (C. 8 anos).

Eu gosto do dia das mães, festa na igreja, Santa Bárbara, Jongo de Santa Bárbara (T. 7 anos).

Gosto da festa da padroeira, Santa Bárbara" (L. 14 anos).

Gosto da festa de Santa Bárbara, só não vou se estiver doente" (G. 12 anos).

As narrativas das crianças apontam o trato, a maneira como os grupos sociais se relacionam no território quilombola e a partir disto como as crianças afirmam suas preferências e maneiras de viverem a religiosidade, culturas e festividades junto aos seus núcleos comunitários.

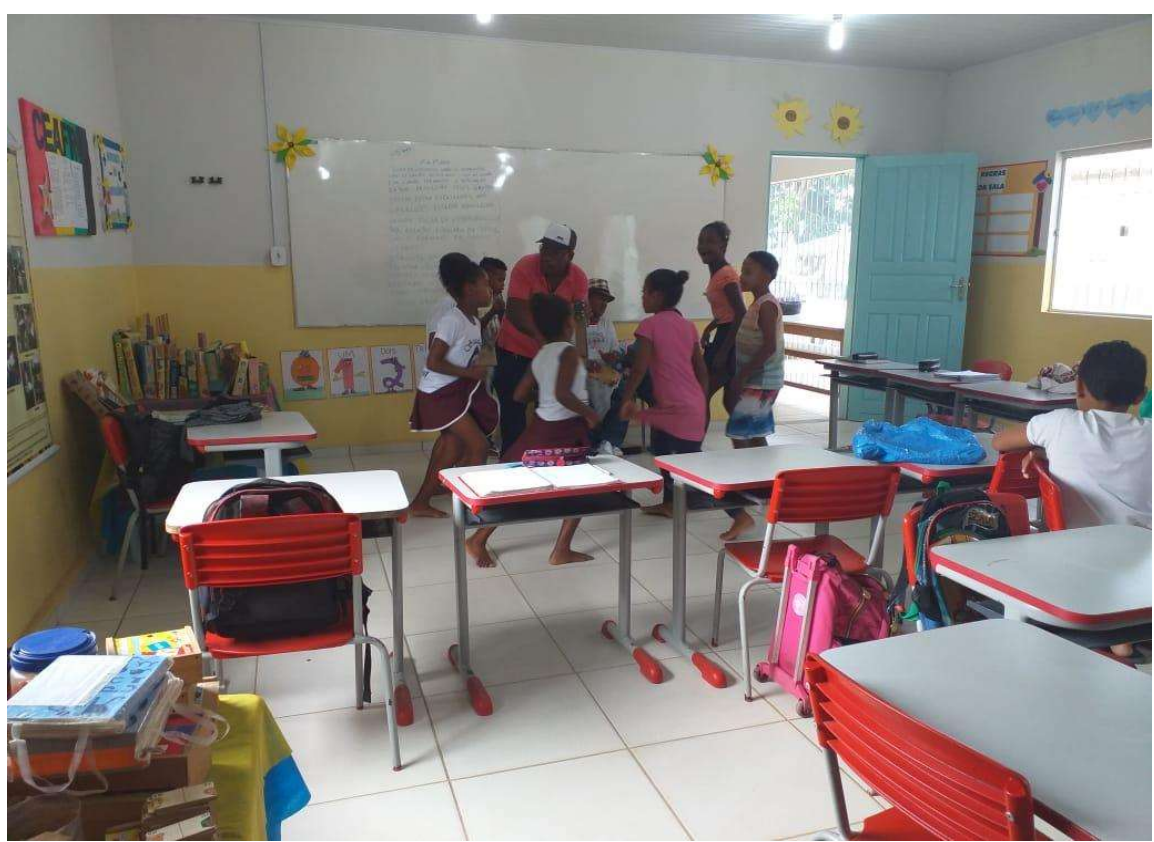

Figura 8 - Aula de cultura- jongo.

Fonte: Acervo das autoras - maio de 2019. 
Elas vivem e sentem as culturas da comunidade e na escola, têm aula de jongo e é para eles/as um dia muito esperado, a aula de Cultura, assim denominada, acontece toda segunda-feira e os mestres jongueiros Anísio e Antônio são responsáveis pelas aulas.

A cultura popular é valorizada, os mestres estão na comunidade e compartilham esses saberes como prática de resistência, na tentativa de manter viva a memória, os saberes e tradição do jongo. Na tentativa de afirmar essas práticas, Hall (1996, p. 152) nos apresenta a seguinte reflexão.

A cultura popular carrega esta ressonância afirmativa por causa da proeminência da palavra "popular". E, em certo sentido, a cultura popular tem sempre sua base em experiências, prazeres, memórias e tradições do povo. Ela se conecta a expectativas e aspirações locais, tragédias locais e cenários locais que são práticas e experiências cotidianas de pessoas comuns.

\section{Os sonhos e as brincadeiras das crianças quilombolas}

Quando conversamos sobre a estrutura da escola, as crianças apontam suas necessidades: querem uma escola com estrutura melhor, pedem uma biblioteca, parquinho novo, quadro novo, mais livros, refeitório grande, mais pratos, mais copos. Uma das narrativas se destacam em nossa análise: "Eu gosto da escola, e a escola precisa de mais espaço, de quadro, e mais estudantes" (P. 10 anos) Para dialogar com essa narrativa, apontamos a seguinte questão a partir da pesquisa de CARRIL (2017, p. 14).

As condições de funcionamento das escolas quilombolas analisadas por Miranda (2012) em comparação com o documento do IPEA revelam similaridades, pois persistem indicadores mostrando precariedade no atendimento aos estudantes, como segue: a maioria dos estabelecimentos é de pequeno porte, com até duas salas de aula $(57,3 \%)$, prevalência que se repete nas regiões Norte $(64,7 \%)$ e Nordeste $(60,3 \%)$. Apenas $15,3 \%$ dos estabelecimentos têm mais de seis salas, enquanto no total da educação básica $51,5 \%$ têm esse mesmo porte (e $22 \%$ contam com mais de dez salas). 
Ao perguntarmos sobre as brincadeiras preferidas na escola e no campo da comunidade, as crianças trazem seus gostos, apresentando diversas brincadeiras e jogos coletivos, demostrando as várias possibilidades e de destaque dentro do brincar e "ser criança" numa comunidade quilombola:

Gosto de brincar de Bambolê, jogo de memória, bola, casinha (E. 7 anos). Gosto de pular corda, pique esconde, bonecas (M. 8 anos).

Gosto de bicicleta e de andar de cavalo (P. 10 anos).

Gosto de pique bandeira, cobra cega, baralho, morto vivo (G. 12 anos).

Gosto de soltar pipa, jogar bola na comunidade (L. 14 anos).

Kramer (2009, p. 170) nos afirma que a palavra "brincar", conforme o idioma (spillen, to play, jouer), apresenta muitos significados, tais como: praticar esportes, dançar, pular, dramatizar uma peça de teatro etc. É na brincadeira que as crianças brincantes reapresentam e ressignificam o que elas vivem e o que sentem, o que criam e recriam, enfim, mostram suas culturas.

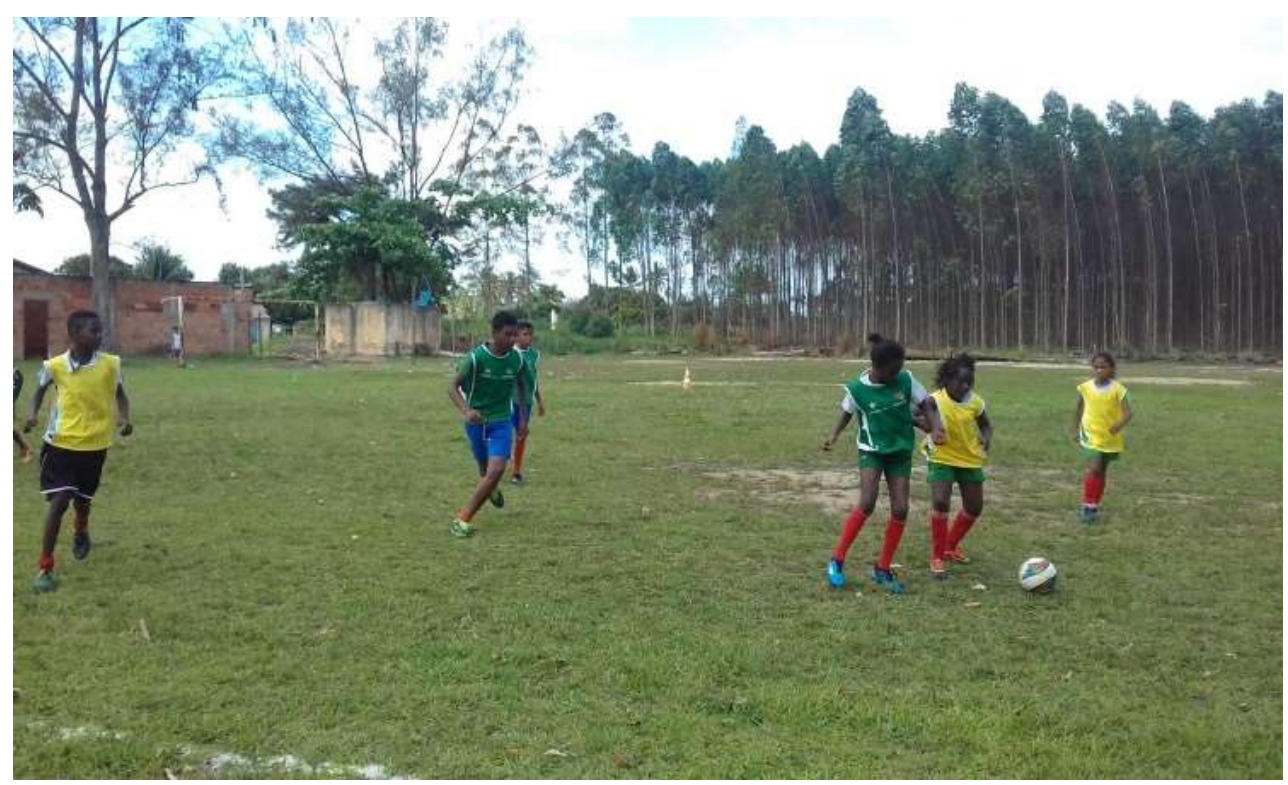

Figura 9 - Crianças praticando esporte-(futebol).

Fonte: Acervo das autoras - maio de 2019. 


\section{Conclusão desse entrelaçar de narrativas e histórias}

Nas narrativas, as crianças apontam seus sonhos, querem ser bombeiro, motoqueiro, bailarino, professor, advogado, taxista, motorista, policial entre outras profissões. Afirmam que a comunidade é legal, bonita, importante, é boa. As professoras são engajadas nos movimentos da comunidade, participam de formações, aceitam os desafios e propostas, o que fez com que essas ações em parceria com a Universidade aconteçam.

Acreditamos que o entrelaçar de saberes, de conhecimentos, narrativas e histórias esteja proporcionando o enriquecimento de todo o processo pedagógico e científico na comunidade envolvida, tanto para os/as estudantes, professoras, comunidade acadêmica, Secretaria de Educação e Núcleo de Estudos Afro-Brasileiro NEAB-UFES. A educação quilombola teve grandes avanços a partir da criação das Diretrizes Curriculares, esses avanços foram em relação ao material didático e alimentação, no entanto, segundo Carril (2017, p. 14), ainda se revela que "são muitas as inseguranças presentes na educação quilombola, envolvendo as condições dos estabelecimentos escolares, o uso de recursos didáticos apropriados e a formação docente".

Alguns desses desafios também são encontrados na Educação quilombola de Linharinho. A EMEF Linhares, no entanto, a escola e seus profissionais apresentam-se em movimento, buscando alternativas, ouvindo as narrativas dos seus estudantes, para que com eles e para eles se construam novos horizontes, nos quais tenham a dignidade de exercerem a busca de seus sonhos, de suas culturas, sem serem violentados em seus direitos. As crianças estão em movimento, assim como suas professoras constroem outro modelo de educação, e acreditamos que esse trabalho se articula com o proposto na LDB/ 96, que expressa o conceito de educação, sendo 
esta ampla que ultrapassa a visão apenas de "ensino escolar". No artigo 1음 visualizamos esse conceito.

A educação deve abranger os processos formativos que se desenvolvem na vida familiar, na convivência humana, no trabalho nas instituições de ensino e pesquisa, nos movimentos sociais e organizações da sociedade civil e nas manifestações culturais (BRASIL, 1996).

Percebemos nesse entrelaçar de narrativas e saberes a possibilidade de buscar alternativas possíveis de rompimento com modelos estáticos fixados em modelo único de conhecimento. As ações percebidas nessa escola apontam possibilidades de como romper com a monocultura do saber e com as contradições pedagógicas. Para esse pensamento, questionamos desde o início das ações, com a seguinte reflexão: Se estamos atuando na formação de professoras/es e lideranças, precisamos trazer as narrativas das crianças, para que por meio dessas vozes possamos entrelaçar conhecimentos, críticas e pensar outras ações para contribuir com a comunidade escolar.

Romper com as contradições é desafiante, mas sabemos que elas são responsáveis por diminuir as riquezas do presente, produzir as ausências, construir e fortalecer a monocultura do saber e sustentar apenas uma visão de mundo. A visão única é um dos primeiros modos de se produzir as ausências em nossa racionalidade ocidental na qual as ciências sociais compartilham. Santos (2007, p. 29) aponta que

\begin{abstract}
A primeira é a monocultura do saber e do rigor: a ideia de que o único saber rigoroso é o saber científico; portanto, outros conhecimentos não têm a validade nem o rigor do conhecimento científico. Essa monocultura reduz de imediato, contrai o presente, porque elimina muita realidade que fica fora das concepções científicas da sociedade, porque há práticas sociais que estão baseadas em conhecimentos populares, conhecimentos indígenas, conhecimentos camponeses, conhecimentos urbanos, mas que não são avaliados como importantes ou rigorosos.
\end{abstract}

Desse modo, concluímos que essa experimentação pedagógica e comunitária se fortalece quando os saberes das comunidades se encontram com o científico e vice- 
versa, quando os conhecimentos e narrativas da comunidade e das crianças recebem o mesmo valor que as linguagens acadêmicas e juntos encontram maneiras outras de se fazer educação comunitária, educação popular, do campo e quilombola. Ouvir as crianças, nos faz acreditar e reafirmar que as suas vozes são necessárias para se pensar qualquer prática e política pública para educação.

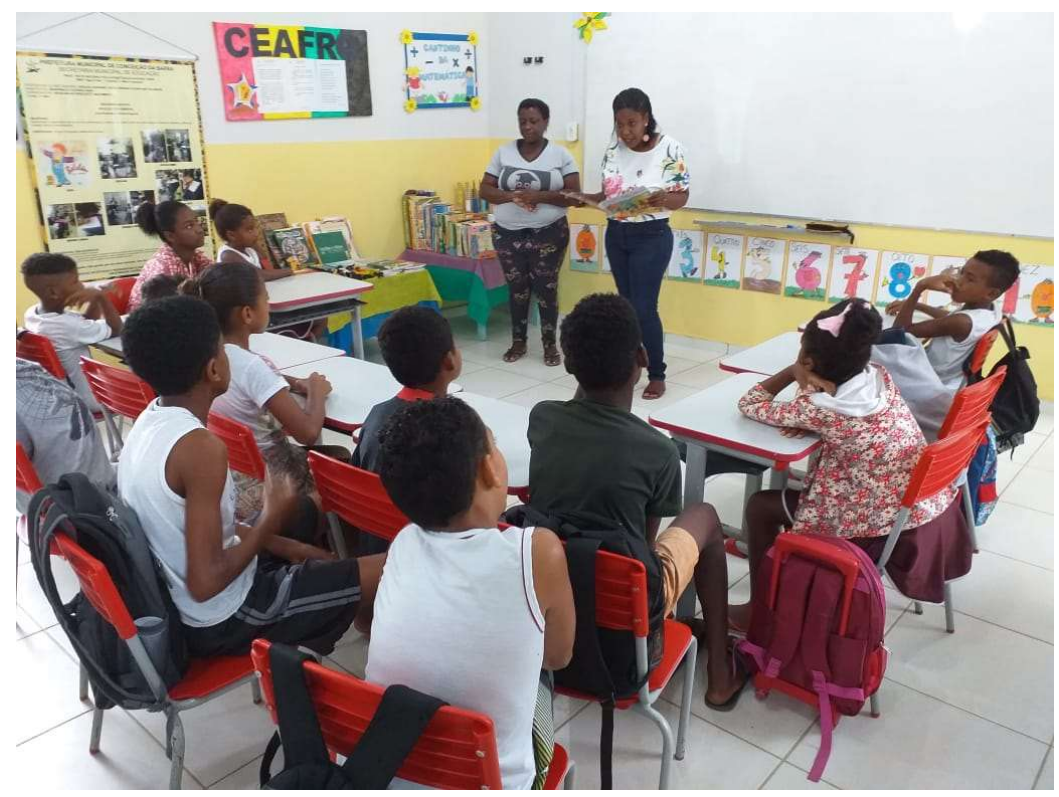

Figura 10 - Momento de leitura.

Fonte: Acervo das autoras - maio de 2019.

Pensar as crianças quilombolas é pensar ações concretas, aliando as teorias para desconstruir o racismo, valorizando as identidades e culturas afro-brasileiras. Citamos Gomes (2005, p. 149) que destaca o seguinte.

Julgo que seria interessante se pudéssemos construir experiências de formação em que os professores pudessem vivenciar analisar e propor estratégias de intervenção que tenham a valorização da cultura negra e a eliminação de práticas racistas como foco principal.

Reafirmamos que a busca das ações demonstradas neste recorte, em forma de artigo, é a demonstração das estratégias de professoras/es e pesquisadoras cunhados 
nas heranças históricas de lutas nos movimentos sociais, movimento negro que sempre esteve na busca de equidade, justiça social, políticas afirmativas e efetivação de uma educação antirracista na forma mais concreta, viva, mutável, orgânica, reflexiva e crítica.

\section{Referências}

ALVES, N. A experiência da diversidade no cotidiano e suas consequências na formação de professoras. In: VICTORIO FILHO, A.; MONTEIRO, S. C. F. (org.). Cultura e conhecimento de professores. Rio de Janeiro: DP\&A, 2002.

ANDRADE, P. G. R. A Educação do negro na comunidade de Monte Alegre - ES em suas práticas de desinvibilização da cultura popular negra. 2007. 192 f. Dissertação (Mestrado em Educação) - Universidade Federal do Espírito Santo, Vitória, Espírito Santo, 2007.

BENJAMIN, W. O Narrador: considerações sobre a obra de Nikolai Leskov. In: Magia e técnica, arte e política: ensaios sobre literatura e história da cultura. São Paulo: Brasiliense, 1994. p. 197-221.

BRASIL. Lei no 9.394, de 20 de dezembro de 1996. Estabelece as diretrizes e bases da educação nacional. Brasília, DF: dez. 1996. Disponível em: http://www.planalto.gov.br/ccivil_03/leis/19394.htm. Acesso em: 23 maio 2019.

. Lei Federal no 10.639, de 09 de janeiro de 2003a. Altera a Lei n 9.394, de 20 de dezembro de 1996, que estabelece as diretrizes e bases da educação nacional, para incluir no currículo oficial da Rede de Ensino a obrigatoriedade da temática "História e Cultura Afro-Brasileira", e dá outras providências. Brasília, DF: jan. 2003. Disponível em: http://www.planalto.gov.br/ccivil_03/leis/2003//10.639.htm. Acesso em: 16 maio 2019.

Decreto no 4.887/2003, de 20 de novembro de 2003b. Regulamenta o procedimento para identificação, reconhecimento, delimitação, demarcação e titulação das terras ocupadas por remanescentes das comunidades dos quilombos de que trata o art. 68 do Ato das Disposições Constitucionais Transitórias. Brasília, DF: nov. 2003. Disponível em:

https://www2.camara.leg.br/legin/fed/decret/2003/decreto-4887-20-novembro2003-497664-norma-pe.html. Acesso em: 13 maio 2019.

Lei $\mathrm{n}$ - 11.645, 10 de março de 2008. Altera a Lei $\mathrm{n}$ - 9.394, de 20 de dezembro de 1996 para incluir no currículo oficial da rede de ensino a 
obrigatoriedade da temática "História e Cultura Afro Brasileira e Indígena". Brasília, DF: mar. 2008. Disponível em: http://www.planalto.gov.br/ccivil_03/_Ato20072010/2008/Lei/L11645.htm. Acesso em: 10 maio 2019.

. Resolução no 4, de 13 de julho de 2010. Define Diretrizes Curriculares Nacionais Gerais para a Educação Básica. Brasília, DF: jul. 2010. Disponível em: http://portal.mec.gov.br/dmdocuments/rceb004_10.pdf. Acesso em: 10 maio 2019. BRASIL. Ministério da Educação. Secretaria de Educação Básica. Secretaria de Educação Continuada, Alfabetização, Diversidade e Inclusão. Diretrizes Curriculares Nacionais da Educação Básica. Brasília, DF: MEC, SEB, DICEI, 2013.

CARRIL, L. F. B. Os desafios da educação quilombola no Brasil: o território como contexto e texto. Rev. Bras. Educ. Rio de Janeiro, v. 22, n. 69, p. 539-564, 2017. Disponível em: http://www.scielo.br/scielo.php?script=sci_arttext\&pid=S141324782017000200539\&lng=en\&nrm=iso. Acesso em: 06 abr. 2020.

CAVALLEIRO, E. S. Do silêncio do lar ao silêncio escolar: racismo, preconceito e discriminação na educação infantil. 6. ed. São Paulo: Contexto, 2012.

CONAQ - Coordenação Nacional de Articulação das Comunidades Negras Rurais Quilombolas. Racismo e violência contra quilombos no Brasil / Terra de Direitos. Curitiba: Terra de Direitos, 2018.

Entrevista Dona Miúda. Disponível em: https://kizoomba.wordpress.com/premiofunarte-de-teatro-miriam-muniz/comunidade-quilombola-de-linharinho-es. Acesso em: 10 maio 2019.

GAUDIO, E. S. Dimensão étnico-racial na educação infantil: um olhar sobre a perspectiva das crianças. In: 37ạ Reunião anual da ANPED - PNE: TENSÕES E PERSPECTIVAS PARA A EDUCAÇÃO PÚBLICA BRASILEIRA. Florianópolis: ANPED, 2015.

GOMES, N. L. Educação e relações raciais: refletindo sobre algumas estratégias de atuação. In: MUNANGA, K. (org.). Superando o racismo na escola. Brasília, DF: MEC, SECADI, 2005.

HALL, S. Critical dialogues in cultural studies. What is this 'black' in black popular culture? Londres, Nova York: Routledge, 1996.

KRAMER, S. Criança e adultos em diferentes contextos: desafios de um percurso de pesquisa sobre infância, cultura e formação. In: SARMENTO, M.; GOUVEA, M. C. S. Estudos da Infância: educação e práticas sociais. 2. ed. Petrópolis: Vozes, 2009. p. 163-169. 
MUNANGA, K. (org.). Uma abordagem conceitual das noções de raça, racismo, identidade e etnia. Palestra proferida no 3은 Seminário Nacional de Relações Raciais e Educação-PENESB-RJ, 05 nov. 2003.

Superando o racismo na escola. 2. ed. revisada. Brasília, DF: Ministério da Educação, Secretaria de Educação Continuada, Alfabetização e Diversidade, 2005.

ORLANDI, E. P. As formas do silêncio no movimento dos sentidos. Campinas: Editora da Unicamp, 1997.

REGO, T. C. Configurações sociais e singularidades: o impacto da escola na constituição dos sujeitos. In: OLIVEIRA, M. K.; SOUZA, D. T. R.; REGO, T. C. (org.). Psicologia, educação e as temáticas da vida contemporânea. São Paulo: Moderna, 2002.

ROMANO. J. Re-leitura da paisagem na Comunidade Quilombola de Linharinho Sob a ótica da teoria da percepção: período entre a chegada do eucalipto e o ano de 2005. UFES. Monografia. 2008.

SANTOS, B. S. Renovar a teoria crítica e reinventar a emancipação social. Tradução: Mouzar Benedito. São Paulo: Boitempo, 2007.

SANTOS, B. S. Para além do pensamento abissal: das linhas globais a uma ecologia dos saberes. In: SANTOS, B. S.; MENESES, M. P. Epistemologias do Sul. São Paulo: Cortez, 2010. p. 31-83.

Enviado em: 31/05/2019

Aprovado em: 21/10/2019 